\title{
Personal Memory and Memory of History
}

\author{
Leonid S. Chernov ${ }^{\mathrm{a}}$ and Elena Iu. Pogorel'skaia ${ }^{\mathrm{b} *}$ \\ ${ }^{a}$ Urals Institute of Administration \\ the Russian Presidential Academy \\ of National Economy and Public Administration \\ 668 Marta Str., Yekaterinburg, 620063, Russia \\ ${ }^{b}$ University for the Humanities \\ 19 Studencheskaia Str., Yekaterinburg, 620049, Russia
}

Received 03.09.2015, received in revised form 26.10.2015, accepted 06.11.2015

The present research substantiates the logical dependence of the memory of history on personal memory. It proves that such logic underlies the classical tradition. Based on some classic Russian literature and Soviet cinematograph, it proves the rationality of the given statement.

Keywords: memory, personal memory, social memory, remember, time, law, war, victory.

DOI: 10.17516/1997-1370-2015-8-11-2734-2742.

Research area: philosophy.

The meaning of the word istoriia ${ }^{l}$ in modern Russian language is transforming in the conceptual sense. Throughout the past several years, mass media has been using the word in the meaning of a thing/object. For example, on the radio we can frequently hear expressions like: eto moia istoriia (this is my story/history), eto ego istoriia (that is his story/history), eto drugaia istoriia (it is a different story), eto chuzhaia istoriia (it is a story of someone else), eto sherstianaia istoriia, kozhanaia, vegetarianskaia, iuzhnaia etc. (it is the history/story of wool, leather, vegetarianism, South etc.) Let us emphasize that istoriia does not stand for "a story about something" with a plot, resolution and conclusion. Saying eto vegetarianskaia istoriia (this is a vegetarian story) the speaker indicates that he changes the topic of the conversation. He spoke about meat, and the words "vegetarian story" mark the beginning of a narration about vegetarians, vegetarianism in general, special recipes etc. Two hours of attentive listening to morning radio programs and making notes is enough to see that istoriia is, first, something really simple; secondly, something indefinite; thirdly, something strictly personal and subjective. In point of fact, istoriia turns into an opinion, the proverbial "world outlook", which is, naturally, different for everyone and therefore is not subject to any evaluation; it makes no sense to analyse it; it is not exposed to any positive criticism.

Such effect in respect with istoriia as "history" is natural though sad. Historical events are losing their scale; a sports event, an opening

(c) Siberian Federal University. All rights reserved

* Corresponding author E-mail address: leon-chernov@yandex.ru, schreibigus@mail.ru 
of a shop, political elections, an expensive purchase are taken as historical events now. What used to be a private example out of many within the framework of big old classic history, is now an event of the history, the world's evening sensation.

The hypothesis of this research is the thesis on the dependence of history on the personal memory of a person. One cannot have history without having memory. If we have a history right away, we become vulnerable in a way that we can be imposed this or that history on ourselves. But still, the term history maintains one of its old meanings used by Hegel or by modern school textbooks. The subjects of history are nations, countries, geniuses, world ideas, providence, not vegetarians, athletes or consumers. Equalling these subjects to each other, let us repeat, would mean that history is open for everyone to do anything in it. That is why we suggest that we consider history from the point of view of personal memory.

There is an interesting episode in "The Idiot" by F.M. Dostoyevsky concerning a money issue. Out of pity, Prince Myshkin gives two hundred fifty roubles to a poor student; the plot of the novel turns in such a way that the student takes this money as an offence from the Prince and returns it in public. The meaning of the gesture is to demonstrate that the student is not a beggar and needs no charity. One of the guests opens the envelope and finds only one hundred roubles inside, not two hundred fifty. Burdovsky (the student) and all his company who come to demand a part of the Prince's inheritance begin to argue that the amount of the returned money does not matter. The gesture of return is performed in order to insult the Prince as much as possible, showing Burdovsky off as a noble man. The company of student Burdovsky is depicted by Dostoyevsky as a new generation of young people, half-socialistic, undereducated, but terribly ambitious. The main thing these young people thrust is the idea of right. They keep repeating that they have a legal right to demand a part of the Prince's inheritance, that they have a right to come into his house, to raise voice at the aristocrats being of non-aristocratic origin themselves. In every utterance poor Burdovsky stumbles and says: "I have a right".

The emphasis on the idea of right and the desire to build a new society on the rightful basis are the distinctive features of our time. However, to understand the basis of right we need to be sure (or at least to try hard to see) that it exists, otherwise we risk assimilating with the company of Burdovsky.

The subject returns the money at a smaller amount than he was given. It is unacceptable from the legal point of view, but from the point of view of the one returning the money it looks spectacular: the money is returned and no one cares how much has been given and taken. As Myshkin gave the money without any receipt, out of his generosity, the payout requires no legal formalities. The fact of the initial presence of a certain amount falls by the wayside. It does not matter anymore whether the money has to be returned or not: it is enough to take it and say: "I don't need your money!" In fact, for Burdovsky both one hundred and two hundred fifty roubles are quite big sums. Psychologically it is not really so important to him how much he returns; to return is the only thing that matters. While logically, as we have just stated, it is acceptable not to return it at all, but just to announce that charity is insulting. However, let us repeat that it involves taking the money and use it at his own discretion.

The right here manifests itself in several forms. The first one is I have a right to demand what belongs to me. No one can take this right away from me as a person. Deceived, Burdovsky believes that he is a rightful heir of Mister 
Pavlishchev, while in fact Myshkin is the one to get the inheritance. The second is the following: Burdovsky wants to be deceived, and, willing to stay confused without understanding the meaning of the legal documents, he makes some gestures and says some speeches about nobility. The law, or the legal understanding of right, and, the most important, the facts are not covered by his arguments. It is essential to understand that Burdovsky and his company, this new generation of young people, need no facts. Their right is based on twisted facts, on the wish to remain confused and, especially relevant, on the nobility of Prince Myshkin. Myshkin is the one to exercise his right to help Burdovsky, he heard the voice of the pleading. In both legal assumptions there is a lie, mispresentation of facts, and deception.

If a person happens to help a poor person and give him five roubles instead of the expected ten, it looks quite "fair" from the point of view of the poor to start a discussion on the greediness of the one who donates so little money.

The right to give alms is my free right, and this is the freedom that creates the fact of the almsgiving. In other words, the fact of giving money depends on myself as a subject, or, to be precise, on myself as a personality. And if we imagine that the beggar begins to demand a certain amount of alms, arguing that he also has a right to possess some money, the beggar loses his freedom of personality, just like does the fact of mercy of the almsgiver. Asking for ten roubles of alms instead of the five roubles given looks like the gluttony of a pet who "thinks" that the first and only task of its owner is feeding it.

Such "demands of right" and gestures of nobility (such as in the case of Burdovsky) can sometimes be extremely convincing. The whole culture of the Enlightenment and, partially, the European art of Romanticism is based on such gestures. But together with liking for such gestures and calls for equality in communication one should remember that for a "person of gesture" like Burdovsky and for his ambitious friends, returning one hundred roubles and returning two hundred fifty roubles is the same. The fact of Myshkin's free mercy turns into their rightful and sincere demand for what they believe belongs to them. Just like Myshkin who could choose whether to give it or not, I can also choose not to return it. And if so, we are legally equal. The fact of the presence of some certain amount of money is transformed into a fact of presence of another amount of money with a gesture=interpretation. We find that Myshkin and Burdovsky are not legally equal, just like personalities are not equal in respect with the memory.

It is not about Myshkin's or someone else's failure to recall something no one else remembers. Let us emphasize that it is not about the amount, not about the weight of a memory. It is about the core of the subject. According to Plato, human memory is an effort about something that happened to the person's soul before his birth. Interpreting Plato's mythological and poetical expression of the significance of memory for a personality, we extract the following. I remember something that is my core. If I can remember the maximum of my core (I like Aristotle's whatness and I believe it is appropriate here), I become a fully-fledged person in this society, such as a politician, a bureaucrat, a clerk etc. If I do not remember what is potentially given to me, I become an "odd" member of the society, such as Onegin or Pechorin.

It is important that in both of these cases I have something to remember. It means that my memory potentially exists, it is present here, and from this point of view it does not matter whether I have or have not remembered it yet. On the other hand, from the point of view of a person living here, in the world of things, I become myself only when I recall something, i.e. I make an effort to remember my whatness. Plato refers to this effort 
as to anamnesis. It assumes desire, animation, and flight of my recalling into the area of memory that makes me myself. Plato gives anamnesis an erotic tone, and it should not confuse us; on the opposite, such understanding of anamnesis emphasizes that we want to remember, that we have a desire to recall. In other words, I do or do not become human to the extent I can actualize my own memory.

One should see a difference between "know much and remember it" and the phenomenon we call "memory actualization". A person may learn a lot, remember this knowledge, be able to use it solving a crossword puzzle, but not more than that. Plato emphasizes that memory is not new knowledge; we do not learn anything new, we only recall what we have previously known. In my memory I recall myself, and without this memory all the other remembered knowledge has very little sense. "Know a lot" has nothing to do with memory. It is impossible to string beads on a non-existent string, on the absence of a string, on something that is not there. With all the beauty of pearls or turquoise, without a binding string, thread or a wire the necklace would not hold, it would fall apart, no matter how nice and expensive the beads are. Let us remark that such type of "remembering oneself" can be also applied to Christian anthropology. The personality is seeking for an "inner self", a divine spark; it returns to the Eden, remembering itself as pristine and pure (interestingly and non-coincidentally, there is a specific prayer anamnesis said during Christian liturgy). Generally speaking, it is the "I need to remember" pattern the Enlightenment era person was also in. For example, Jean-Jacques Rousseau suggested to "remember" that a person in its core is kind, naïve and honest. L.N. Tolstoy "remembered" that it is necessary to live simply, like peasants, or like trees in the forest. In his letter to Gogol V.G. Belinsky "remembered" that the first socialist was no one but Jesus himself.
Psychoanalysis and modern psychotherapy in many of its variants are based on the fact that the patient remembers things that happened to him long ago by himself. That is the value: not to present a document (event) from the past as a fact of someone's archive, but to help the patient to reach the fact of the past on his own.

In all these cases, though different in the core, we can see that memory underlies the personality model; a personality is impossible without it, understanding one's own self is impossible without it. It serves as a reservoir for personal growth, personal desires and simultaneously the purpose, the entelechy of the personality. Without a stable memory structure, the anthropological frame is also lost. However, the persons having the memory and actualizing it are not equal; that is what makes them individuals. Just like it is natural and evident that there are no same beads, there are no same memories. Diamond chaplets, precious stone necklaces, wooden rosary and children's hand-made jewellery of dried berries are just as unequal as Prince Myshkin and student Burdovsky in respect of their rights. There is no uniformity between them and there can never be. There is only being, only the memory being fact.

Being is associated with right thinking. Right remembering means right thinking. That is why to manipulate one's memories means manipulating a person in general and the things surrounding him.

Besides a number of new objectives and tasks, the phenomenology of the early $20^{\text {th }}$ century attempts to solve the problem of retaining the wholeness of the subjects by using the memory mechanisms. In the essence, E. Husserl dares to undertake an impossible task. He attempts to build a pattern of remembering all previous experiences in the integrity of the conditions of the person's consciousness and its contents. In other words, he tries to stop the time, just like Faust did, being simultaneously here and 
in Plato's world of ideas. It was even beyond Socrates' power, so the attempt itself deserves the greatest respect to the founder of phenomenology science. The result of such project should be a rational, scientific, and, first of all, integral subject. A different consequence shall be a real, material, textured thing. Thing as a fact, thing as an object I can remember. Let those be the famous boots of Heidegger (Van Gogh), a bowl, a stone, a bell, a roadside bench, an inkpot, a rose or Proust's cookie. It is right to recall a thing, or, speaking the language of phenomenology, to see and describe it in the right way; it means to see the thing as it is, and, consequently, to possess it, to move it from place to place, to embosom it etc. In other words, it means to live with this thing. Let us emphasize, to live with this very thing, not another. As we remember, that was two hundred fifty roubles that Myshkin gave Burdovsky, not one hundred.

Now let us imagine that my personal memory is damaged. I certainly do not remember any events of my past, I do not remember my surroundings and the things I lived with and the events they were connected with. There are some memory facts, but they are vague, segmental, and discreet: complete amnesia is a rare phenomenon. The segmental facts do not make up a whole picture. But as we have already stated, a personality cannot exist without the attempts to remember itself. In the case of partial amnesia we deal with either partial, incomplete personality, or we are trying to restore this personality with the help of a different memory, which is social, collective one. Any traditional upbringing assumes that a person expelled from the society risks losing its wholeness and that is the reason why tradition "presents", "drafts", "models" the personal memory. In this modelling process social memory can be both behind, like myths, legends, historical events, heroes, victories, family legends, and ahead, as a social ideal.
To become a Stierlitz, cosmonaut, Fantômas, Terminator, as the mass culture offers, I either need to have no personal memory at all, relying on the social one completely, or to develop some spying features, dexterity etc., depending on my inclinations. Having consciously chosen the way of a cosmonaut, I make a sober estimate of my talents, physical condition, intellectual resources. Without this estimate, without the "self-recalling" work of my memory I become nothing but a kitchen maid ruling the country, or a zombie/ robot, blindly following its master's orders.

It is common for historians to think that during the High Classical period Greece had no sense of history and the past. If so, we arrive at the conclusion that the Greeks were guided by a heroic personality. Such personality is mostly geared to the eternal future and full self-realization. Achilles knows of his death, but he also knows that before he dies young he will have accomplished enough feats to be remembered by his successors forever. The personal memory support is essential, but it is nothing but support required to keep the person/subject within the limits of wholeness. Achilles is meant to be a hero and he becomes one. Possessing its own, conventionally speaking, "healthy" and full memory, a subject can always restore the history of things from the events of the past and make a step into the future. The motto of the Enlightenment: "Wake up, Duke, there are some great deeds waiting for you!" means that it is a personality that creates history; that the great deeds will be done by the one who has just got up from the bed. The great deeds will be just "waiting"; as they are, their greatness is only potential, and without the person's interference they will just continue waiting for their time.

Turning to some later historical example of interaction between the social and personal memory, then, for example, Jung's analytical psychology is also targeted at the restoration and retrieval of personal memory with the help 
of the race memory. Let us emphasize, that even though Jung is often accused of impersonalism, personality is primary for any therapy, starting from Socrates'.

Let us state it once again: the opposition of "personal memory - social memory", first of all, saves the subject, the person. Social memory helps a subject, while a subject actualizes itself, thereby maintaining the tradition. To become social, the memory first has to be mine, i.e. personal. Just like a sports car or a truck is primarily a vehicle, and its function as of a sports car or a truck is secondary, any memory is primarily the memory of oneself, and secondarily a memory of whatever else. Even though this conclusion is not so evident in the era of manipulation and total control of the idea of reality and the existence of multiple "memory policies", we shall repeat that it is located entirely within the limits of classical philosophy, the philosophy of Plato and Aristotle in particular and, as it has been mentioned above, phenomenological philosophy as well.

A good illustration of this sort of connection between personal and collective memory is, to our mind, the poem by Robert Rozhdestvensky that became the "Song about Far Native Land" that played in the famous Soviet film "Seventeen Moments of Spring". The combination of the lyrics with the image of the spy Isaev and the plot of the film expressively demonstrate the logic of correlation between personal and collective memory. In its structure, the logic coincides with the one presented in this article.

Let us quote several lines from "Song about Far Native Land": "Oh, my shore, please appear to me // As an edge, as a thin line though... // Oh, my shore, so tender been, // How I do wish to swim to you now, // From this place to swim to you some time... // And there's the mushroom rain, somewhere it is rain, // And cherry-trees bow to earth // In the garden small on the river bank // They grow there for long... // And somewhere far, in my memory // I feel warmth as being a child, // Though snow has covered my mind with a thick and white layer... // You, the storm, would you give me a drink, // Not to death, but to drunken state... // And again, as if it's the last blink, // I look somewhere into heaven, // As if I'm seeking answer... ${ }^{2}$ (bold by the author)

The memory is described in spatial, not temporal dimension: "far", "covered with a thick and white layer", "earth". It is not as much about childhood as about something that is not here anymore though it once has been. In respect of childhood, the "now" moment is emphasized. Everything that happened there is now. Recalling himself, the subject of the memory is aspiring to move where he wants to "swim", he is willing to reach the "shore". It is memory that gives him the strength to "swim", i.e. it is the driver of the movement and in this respect it is directed at the future. Without this memory of the mushroom rains and cherries there is no future. At the same time we think of death, of the "last time" and we "are seeking answer". As the idea of death does not appear from the childhood itself, it means that the movement forward goes so far that death becomes visible. The idea of death is reflexive; the protagonist of the poem realizes that "to the drunken state" does not mean "to death". But still the question of death is up. The "last time" is the possibility of losing memory, and, consequently, terminating the trip to the faraway shore, i.e. to the future. The war the film is dedicated to is that state where death may be encountered at any moment.

In the film the subject of such memory, being in the position of "now", thinking of death, trying to reach the future shore with the help of his memory, is the man of war, the film character colonel Isaev (Stierlitz). And though in the film the song plays off screen and it is not the main character performing it, the perception of the audience correlates the lyrics and content of 
the song, first of all, with the situation of Isaev. The narrator in the song and Isaev (Stierlitz) are perceived as one and the same person.

The protagonist begs his sadness and pain to "fly" to his home; "My sharp pain, would you go away..." - he says in the first line, and "My grief... // Would you fly as a grey cloud far // ... From this place to native land of mine..." - he says in the last. Evidently, it is a message home, a letter of sadness and pain. Through this purely existential and personal experience, the "painful feeling" the subject of the memory attempts to reach his native shore. It is especially important that the protagonist directly says: "I beg", "I look", "Give me a drink", thereby realizing and bringing all temporal and spatial ideas altogether. The past in the "now like in the childhood" mode, the future as a faraway shore, death and the last time are consolidated with the realized I that remembers all the smallest things and details ("mushroom rains", "cherry-trees bowing to earth"). These trifles and certain facts of the past form the framework / structure / base / foundation of the personality, and it is there, "home", the protagonist begs his grief and pain to go. All these facts are both in the past and future, though it is evident that I of the future does not exist anymore, but there is the desire, the hope to achieve it, just like there is a hope to win, without which the victory would never happen.

Stierlitz is a character of the extremely sophisticated temporal structure of "I". He finds himself in a continuous borderline situation. If on the open front every attack is followed by the everyday frontline life, every partisan raid is followed by going underground, to the forest or a camp, Isaev (Stierlitz) in this regard is always simultaneously here and there. Here, in Germany, he is Stierlitz, while in his motherland he is Isaev. These two faces are for the others, while "inside himself" he is only identified with a Soviet intelligence colonel. His objective is to finally win the war, bring the victory closer. All his inner powers are targeted at this, and, basically, the main topic of the film is solving the problems he faces. Seeing Stierlitz and calling him "Stierlitz", amazed by his calmness, we know that Stierlitz is Isaev. To make sure we do not forget it, the E. Kopelyan keeps reminding us from off screen that Stierlitz is Isaev. The past of Isaev and his memory are the sources of his integrity, it remembers the little details (the small garden, cherry-trees, mushroom rains); here it is purely personal. It is in the past where the true secret name of Isaev, Vsevolod Vladimirovich, is hidden. For him social memory acts as a task, an order.

And in this sense the duty to the order and the law of honour empower Isaev (Stierlitz) to continuously restore his personal memory. For example, the murder of a traitor/enemy is excused by the situation of war and the given order. At first glance it seems that the social (the duty, the task) is the primary of Stierlitz, while the personal is oppressed, pushed back and forgotten.

However, his personal memory is just "covered"; it is neither hidden, forgotten nor "switched off" for a while until the victory. It is covered as something that is carefully stored. It is clear, because in the hardest moments the memory of the past is "retrieved" from its safe to fill all the deeds with meaning. It is important to understand why the grief and pain that overfill the life of Isaev (Stierlitz) and similar heroes of the war "fall into" the same memory, flying "home". Not just anywhere, not to the place of destruction, not to the desert where the Jews would release their scapegoat, but home. The answer is simple: the personality cannot stand the tension; it is natural to release the grief and pain it suffers. But where is this reservoir? It is in the past, in that memory that is covered under the "thick white layer". This memory of the past is so "sound", natural and firm, that grief and 
pain make no harm to it. Moreover, in the case of necessity one would have to run for this personal memory again to seek help; the memory of the past has enhanced with the grief and pain; and it will continue forever, as this process is endless. As Plotin spoke of the Unified, comparing the Unified with the Sun: "It gives without getting smaller". We give grief and pain to get power and hope in return. The past cannot do it on its own, but hope points at the future goal: it points home. The post-war home of the future, where everyone knows of the Great Victory, is filled with pain and grief, but it is a faraway dream and a goal. The past has become the future. In the future the fulfilment of an order and duty are the realizations of the collective maxima. The past keeps the resource and the childhood facts. And the present is where the personality which keeps the three temporal states in itself lives.

The social duty of Isaev (Stierlitz) cannot rely on itself only; it requires the personal form of this duty embodied in the personal memory. Just like betrayal which, though concerns the society, lies deep in the personality of the traitor, the social remembering lies deep in the memory of a single personality.

The interaction between the personal and social memories described above acutely reveals itself in respect with such phenomenon as war and such people as the participants and heroes of the war. It has become too common for us to see armies fight, hundreds of thousands and millions die and the "regime" or ideology win. These are all the facts of statistics, just like it is a fact the fighting ones are the people with the living bundle of personal memory. In the film "Ivan's Childhood" by A.A. Tarkovsky the scenes of war life is followed by the dreams of the main character, the teenage spy Ivan. And the dreams where Ivan plays with his sister, talks to his mother, do make up the true life of the boy. And in one of those dreams in the final of the film, where the viewer knows about the execution of Ivan, he runs away on the water towards the sun. The film of war, sacrifice and the death of the child turn into a film of personal victory within one country and one nation, while all personalities of the film: Ivan, Kholin, Galtsev, Masha are different. Just like Myshkin and Burdovsky were.

\footnotetext{
1 Translator's note: Russian word «история» istoriia has two meanings: story and history.

2 Translated by Lyudmila Purgina http://www.poemhunter.com/poem/r-rozhdestvensky-the-song-about-far-native-landtransl-rus/
}

\section{References}

Husserl, E. Fenomenologiia vnutrennego soznaniia vremeni [Phenomenology and the consciousness of internal time]. Moscow, Gnozis, 1994.

Dostoyevsky, F.M. Idiot [The idiot], novel. Petrozavodsk, Kareliia, 1982.

Plato. Fedr [The Phaedrus. Collection of works in four volumes]. Moscow, Mysl', 1993. Vol. 2, pp. 135-192.

Rozhdestvensky, R. Eto vremia [This time], poems. Moscow: Sovetskii Pisatel', 1983.

Salynskii, D. Kinogermenevtika Tarkovskogo [Cinema hermeneutics of Tarkovsky]. Moscow, Kvadriga, 2009. 


\section{Личная память и память историческая}

\section{Л.С. Чернов ${ }^{\mathbf{a}}$ Е.Ю. Погорельская ${ }^{\sigma}$}

а Уральский институт управления филиал Российской академии народного хозяйства и государственной службы при Президенте РФ Россия, 620063, Екатеринбург, ул. 8 Марта, 66 ${ }^{\circ} Г$ уманитарный университет Россия, 620049, Екатеринбурга, ул. Студенческая, 19

В работе обосновывается логическая зависимость исторической памяти от памяти личностной. Доказывается, что подобного рода логика находится в основании классической традииии. На примерах классической русской литературы и советского кино доказывается правомочность данного положения.

Ключевые слова: память, личная память, общественная память, вспомнить, время, право, война, победа.

Научная специальность: 09.00.00. - философские науки. 